\title{
PEMBERDAYAAN DAN PENGUATAN DAYA SAING USAHA DENGAN PENERAPAN LEAN SIX-SIGMA CONCEPT, STUDI KASUS
}

\author{
Hari Supriyanto \\ Industrial Engineering Department, Sepuluh Nopember Institute of Technology \\ Kampus ITS Sukolilo, Surabaya 60111 \\ Email: hariqive@yahoo.com
}

\begin{abstract}
Abstrak
Dinamika dan perkembangan ekonomi global dapat memberikan sinyal positif terhadap pentingnya peningkatan pemberdayaan dan daya saing produk di pasar. Dibutuhkan pemikiran untuk membangun keunggulan kompetitif, yang menjadi dasar bagi peningkatan produksi dan daya saing bisnis. Peningkatan produksi merupakan serangkaian aktifitas untuk membentuk produktifitas. Bila salah satu aktifitas produksi mengalami kegagalam maka akan berpengaruh pada kualitas dan kapasitas produksi. Kegagalan biasanya terindikasi dari waste/ pemborosan yang muncul di sepanjang value stream. Terdapat indikasi defect yang tinggi melebihi $10 \%$ di sortir dan packaging process. Permasalahan utama adalah adanya waste/ pemborosan yang mengakibatkan penurunan kualitas dan kapasitas produksi. Paper ini akan mengidentifikasi waste yang terjadi di proses produksi, mencari akar penyebab terjadinya waste, dan membangun alternatif solusi perbaikan. Diperlukan pemikiran kreatif untuk dapat menaikkan efisiensi sumber daya dan daya saing bisnis di pasar. Metoda yang dipakai untuk menyelesaikan permasalahan adalah Lean six-sigma. Konsep ini menelusuri permasalahan inefisiensi dengan mencari non value added activity dari munculnya waste di sepanjang value stream. Kemunculan waste selanjutnya diidentifikasi lebih dalam dengan root cause analisys (RCA) dan failure mode and effects analysis (FMEA). Hasil akhir dari FMEA adalah risk priority number (RPN) yang menggambarkan prioritas atas mode resiko untuk dilakukan perbaikan. Dari hasil prioritas dirancang 3 alternatif perbaikan yaitu pelatihan operator, pembuatan SOP proses produksi, dan pelatihan karyawan quality control. Dengan pendekatan net present value (NPV), maka diperoleh nilai NPV yang positif, artinya alternatif tersebut adalah layak untuk dijalankan. Alternatif ini meningkatkan nilai sigma dari sigma awal sebesar 2,80 menjadi 3,30. Kenaikan nilai sigma akan memberi indikasi adanya penurunan tingkat defect per million opportunities (DPMO), dan berakibat pada penurunan biaya sampai $20 \%$.
\end{abstract}

Kata Kunci: daya saing, kompetitif, Lean Six Sigma, Waste, RCA, FMEA.

\begin{abstract}
The dynamics and development of the global economy can provide a positive signal on the importance of enhancing the empowerment and competitiveness of products in the market. It takes thought to build competitive advantage, is the basis for increased production and business competitiveness. Increased production is a series of activities to form productivity. If one of the production activities fails then it will affect the quality and production capacity.

Failure is usually indicated by the waste that appears along the value stream. There are high defect indications exceeding $10 \%$ in sorting and packaging process. The
\end{abstract}


main problem is the presence of waste resulting in decreased quality and production capacity. This paper will identify the waste that occurs in the production process, find the root cause of the waste, and build alternative solutions for improvement. Creative thinking is required to increase resource efficiency, and business competitiveness in the marketplace. The method used to solve the problem is Lean six-sigma. This concept traces the inefficiency problem by finding non-value added activity, from the emergence of waste along the value stream. The appearance of the waste is further identified deeper with root cause analysis (RCA) and failure mode and effects analysis (FMEA). The end result of FMEA is the risk priority number (RPN) which describes the priority over the risk mode, for improvement. From the priority result, 3 alternatives were designed namely operator training, SOP production process, and quality control employee training. With the net present value (NPV) approach, the positive value of NPV is obtained, meaning that the alternative is feasible to run. This alternative increases the sigma value of the initial sigma by 2.80 to 3.30. The increase in sigma value will give an indication of a decrease in the level of defect per million opportunities (DPMO), and result in a reduction in costs up to $20 \%$.

Keywords: daya saing, kompetitif, Lean Six Sigma, Waste, RCA, FMEA.

\section{PENDAHULUAN}

Kebutuhan konsumen, dinamika pasar, dan pertumbuhan ekonomi memiliki peluang yang besar untuk memanfaatkan keunggulan bersaing perusahaan dengan cara meningkatkan skala ekonomi; ini adalah basis untuk mendapatkan margin keuntungan, dan menjadikan daya saing sebagai momentum untuk memacu pertumbuhan produksi. Meningkatnya pertumbuhan produksi diharapkan dapat menstimulus perkembangan teknologi, pengembangan sumber daya manusia dan mengatasi masalah tenaga kerja. Dibutuhkan pemikiran untuk membangun keunggulan kompetitif, yang menjadi dasar baru bagi peningkatan daya saing bisnis (Taylor and Brunt, 2001). Pemahaman mengenai pentingnya daya saing berkembang seiring dengan semakin berkembangnya globalisasi dan perdagangan bebas. Daya saing secara garis besar diukur berdasarkan kondisi institusi, kebijakan, pemberdayaan dan faktor-faktor yang menentukan tingkat produktivitas perushaan. Produktivitas yang tinggi mencerminkan daya saing tinggi dan daya saing tinggi berpotensi menghasilkan pertumbuhan perusahaan yang tinggi (Ga et al., 2011). Daya saing tinggi menuntut adanya "prasyarat dasar" yang harus dipenuhi, untuk memuaskan konsumen dan pasar. Faktor inovasi produk adalah yang menjadi penentu dalam keberhasilan pemberdayaan (empowerment) dan penguatan daya saing bisnis. Pelaksanaan peningkatan daya saing bisnis saat ini terkendala beberapa hambatan, dan menghambat pertumbuhan bisnis. Prospek usaha yang kurang jelas serta perencanaan, visi dan misi yang belum mantap, kurangnya permodalan, dan kualitas sumber daya manusia adalah beberapa kendala yang selalu menjadi hambatan.

Data perusahaan menunjukkan bahwa reject produk di lapangan masih berkisar di angka $10 \%$ bahkan lebih. Prosentase ini memberi indikasi awal yang tidak baik dan berdampak terhadap timbulnya problem dan pemborosan. Ini menandakan bahwa di dalam proses masih terdapat tingginya nonvalue added activity. Aktifitas ini mengindikasikan adanya nilai sigma yang rendah; dari perhitungan awal berkisar pada 2.8 sigma. Pemborosan dalam brntuk reject yang tinggi memberi tanda adanya dampak terhadap produk yang dilempar ke pasar. Indikasi ini merupakan problem produksi yang harus diperbaiki. Diperlukan studi lebih lanjut untuk mengetahui faktor kritis penyumbang terjadinya waste ini. Reject produk yang 
tinggi akan menyerap biaya kualitas yang semakin besar, termasuk di dalamnya adalah cost of non quality. Upaya-upaya perbaikan kualitas produk dapat dilakukan dengan berbagai metode dan konsep. Lean six sigma merupakan salah satu jawaban bagi perusahaan yang memiliki masalah dibidang reject di sepanjang production flow process.

Sedikit sekali diantara banyak improvement yang dilakukan dengan mempertimbangkan biaya kualitas. Tulisan ini, memperkenalkan aplikasi proses improvement dengan mengintegrasikan metode lean, dan six sigma. Identifikasi waste dilakukan berdasarkan pada, Defect, Over Production, Waiting, Not utilizing employee, Transportation, Inventory, Motion, dan Excessive processing waste.

Berdasarkan permasalahan di atas, maka tujuan yang ingin dicapai adalah identifikasi waste yang terjadi di sepanjang proses produksi, mencari akar penyebab permasalahan dan memberikan alternatif solusi yang mungkin dilakukan perusahaan untuk mengurangi dampak timbulnya waste.

\section{TINJAUAN PUSTAKA}

Kontribusi industri kecil dan menengah (IKM) dalam perkembangan perekonomian Indonesia cukup besar, ini dapat dilihat di Jawa Timur yang $73.51 \%$ nilai produksi industri dikuasai oleh industri kecil dan menengah (Dinas Perindustrian dan Perdagangan Provinsi Jawa Timur, 2013). Peningkatan permintaan produk berkualitas tinggi oleh perusahaan besar memaksa IKM untuk memperhitungkan implementasi peningkatan kualitas secara terus menerus dalam strategi bisnisnya (Gibbons and Burgers, 2010). Selama ini IKM di Indonesia mempunyai kendala dalam memenuhi spesifikasi agar mencapai standar yang telah ditetapkan. Persoalan ini mendorong IKM untuk meningkatkan kualitasnya, baik dari segi produk, pelayanan, ataupun organisasi. Kualitas sendiri dapat diartikan sebagai tingkat atau kesesuaian suatu produk dengan pemakainya, dalam arti sempit kualitas diartikan sebagai tingkat kesesuaian produk dengan standar yang telah ditetapkan (Pande et al., 2002.). Untuk itu fihak industri harus memberikan pelayanan terbaiknya kepada konsumen. Kualitas produk secara terus menerus harus dijamin dan dijaga. Penerapan Quality control telah menjadi perhatian khusus bagi perusahaan seiring kemajuan teknik pengendalian, terutama untuk memenuhi permintaan ekspor yang semakin tinggi.

Kualitas merupakan kemampuan produk atau jasa untuk dapat memuaskan bebutuhan konsumen. Diketahui bahwa konsumen sebagai pemakai produk akan semakin kritis dalam memilih atau memakai produk, Kualitas dapat digambarkan sebagai keseluruhan karakteristik dari produk atau jasa yang dihasilkan dari proses manajemen. Kebutuhan konsumen yang bersifat kritis ini mengakibatkan peranan peningkatan kualitas semakin penting. Bebagai macam metode dikembangkan untuk mewujudkan kondisi ideal dalam proses produksi yaitu zero defect atau produksi tanpa cacat. Salah satu studi yang cukup revolusioner adalah penerapan six sigma. Studi ini dikembangkan oleh Motorola. Studi ini dapat dikatakan berhasil, meskipun belum mampu mewujudkan kondisi zero defect. Konsep six-sigma menerapkan kondisi bahwa diharapkan mampu menekan defect sampai 3,4 per satu juta kesempatan (Harisupriyanto and Diesta, 2017). Konsep ini menekankan pada pebaikan proses yang terus menerus.

Produk yang dipakai sebagai penelitian adalah kacang olahan. Produk ini sebagian untuk dieksport sehingga produk ini harus mempunyai kualitas tinggi. Sementara itu dari data didapatkan bahwa produk tersebut memiliki prosentase defect yang cukup tinggi. Indikator lainnya adalah bahwa terdapat sejumlah produk yang tidak dapat dikemas sesuai kualitas yang diharapkan. Indikator ini merupakan problem yang perlu untuk diperbaiki. Fokus utama adalah pada proses sortir dan pada proses packaging/pengemasan. Pemetaan awal didapatkan bahwa penyebab terjadinya produk cacat adalah karena 
kegagalan pada proses packaging. Sementara itu diantara proses lainnnya terdapat waste yang menyebabkan menurunnya kualitas produk. Ini mengakibatkan biaya yang semakin tinggi. Sistem pengendalian kualitas perlu dilakukan, dimulai dari bahan baku sampai produk akhir. Untuk menyelesaikan permasalahan tersebut dipakai kombinasi dari pendekatan Lean, dan six-sigma untuk dapat mengetahui waste yang disinyalir dapat manurunkan kualitas produk. Pemikiran Lean Six-Sigma perlu disebarluaskan ke seluruh bagian tanpa memandang tipe industri atau tipe kegiatan. Lean Manufacturing atau Lean Thinking (Gibbons, and Burgers, 2010) memiliki filosofi untuk mencapai perbaikan dengan cara yang paling ekonomis dengan fokus pada pengurangan waste. Konsep ini menjadi salah satu konsep terpenting dalam kegiatan peningkatan kualitas; filosofi ini selanjutnya disebut Toyota Production SystemTPS di Jepang. Fokus utama Lean adalah pada informasi dan membangun value adding di sepanjang aliran proses sedangkan six sigma dapat membantu untuk mengidentifikasi, menangani dan memperbaiki kinerja yang buruk. Banyak prinsip lean pada dasarnya didasarkan pada model kualitatif dan dikembangkan dari penelitian yang panjang. Six Sigma di sisi lain dapat memainkan peran penting dalam memahami problem yang terjadi di sepanjang aliran proses. Keduanya dapat disatukan menjadi metodologi Lean Six Sigma (LSS). Sama seperti gambar di bawah ini yang menunjukkan hubungan kuat antara lean dan six sigma untuk meningkatkan kinerja organisasi. Dengan demikian Lean Six-Sigma dapat diterapkan dalam semua proses. Lean Six Sigma yang diterapkan dalam industri manufaktur akan menjadi Lean SixSigma Manufacturing (Harisupriyanto, 2013). Keterkaitan kedua konsep dapat dilihat pada gambar 1 di bawah ini.
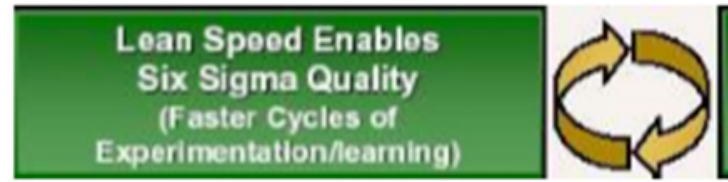

Six Sigma Quality Enables Loan Spoed

(Fewer Dofects Means

Less Time Spent on Rework)

Gambar 1. Keterkaitan Lean dan Six Sigma

\section{METODE PENELITIAN}

Konsep dan pendekatan lean manufacturing adalah pendekatan yang sifatnya sistematis untuk mengidentifikasi inefiensi sumber daya dan mengeliminasi adanya waste (pemborosan) melalui continuous process improvement (Hines et al. 2000). Prinsip dari lean manufacturing adalah memperbanyak added value activity dengan mengurangi waste. Waste diidentifikasikan sebagai idle time dimana tidak ada nilai tambah pada produk atau jasa. Strategi lean manufacturing adalah memberikan kemampuan pada perusahaan untuk berkompetisi dengan cara mengurangi biaya dan meningkatkan kualitas. Target dari lean manufacturing adalah mengurangi 8 kategori waste (Hines and Taylor, 2000; Vincent Gasperz. 2007) meliputi Overproduction, Motion, Inventory,
Waiting, Underutilized People, Defects, dan Inappropriate Processing Untuk mengidentifikasi adanya aktifitas yang tidak bernilai tambah maka digunakan quality improvement. Quality improvement adalah upaya yang terus menerus yang harus dijalankan oleh menejemen perusahaan. Tujuan utamanya adalah untuk mereduksi adanya pemborosan (waste) yang biasanya terindikasi dengan timbulnya non value added activity (Ga et al. 2011.).

Secara umum metodologi yang dipakai akan mengikuti tiga tahap, yaitu tahap informasi dan identifikasi, tahap analisa, dan tahap generate alternative.

Tahap petama, informasi dan identifikasi, tahap ini mirip dengan tahap pertama define; adalah tahap pencarian informasi yang berhubungan dengan problem. Diperlukan identifikasi awal berupa mapping proses 
produksi yang bertujuan untuk memetakan seluruh proses. Salah satu tools mapping adalah big picture mapping (Taylor and Brunt, 2001). Dari identifikasi tersebut penelusuran problem terutama waste (pemborosan) akan diketahui. Pemborosan sering terindikasi dari adanya non value added activity. Pada tahap awal ini berdasarkan pada data maka dapat dihitung nilai sigma awal.

Tahap kedua, analisa. Dari tahap pertama selanjutnya dilakukan analisa untuk menentukan aktifitas dari waste kritis. Selanjutnya dicari akar penyebab masalah dengan RCA (root cause analysis). Untuk mengetahui prioritas atas kekritisan dipakai perhitungan RPN (risk priority number) dengan pendekatan FMEA (failure mode and effect analisys).

Tahap ketiga, build alternative. Tahap ini dimulai dari generate alternative yang memungkinkan untuk dijalankan perusahaan. Pemilihan didasarkan pada prioritas dari risk priority number (RPN) yang diperoleh dari FMEA. Langkah terakhir adalah pemilihan alternatif terbaik.

\section{HASIL}

Produk kacang olahan merupakan kelompok food industry dan memiliki sejarah yang cukup panjang. Produk ini dimulai dari home industry dengan pengolahan yang sederhana. Seiring dengan meningkatnya permintaan pasar, pertumbuhan industri kacang garing ini semakin menuju arah yang lebih baik. Sebagian produk harus mempunyai kualitas tinggi, dan produk ini tergategorikan dalam produk eksport. Dari data awal didapatkan bahwa produk tersebut memiliki jumlah defect yang cukup tinggi, di atas 10\%. Dibutuhkan pemikiran untuk membangun keunggulan kompetitif, yang menjadi dasar baru bagi peningkatan daya saing perusahaan (Dora et al. 2014.). Pentingnya faktor daya saing menjadi berkembang seiring dengan semakin berkembangnya produk di pasar global. Kemampuan untuk menurunkan tingkat defect waste adalah salah satu faktor untuk membangun pemberdayaan dan daya saing produk. Artinya bahwa kepuasan konsumen adalah merupakan inti di dalam membangun, memberdayaan dan menaikkan daya saing produk

Proses produksi kacang olahan dapat digambarkan dalam bentuk Big Picture Mapping (Taylor and Brunt, 2001) seperti pada gambar 2 di bawah ini.

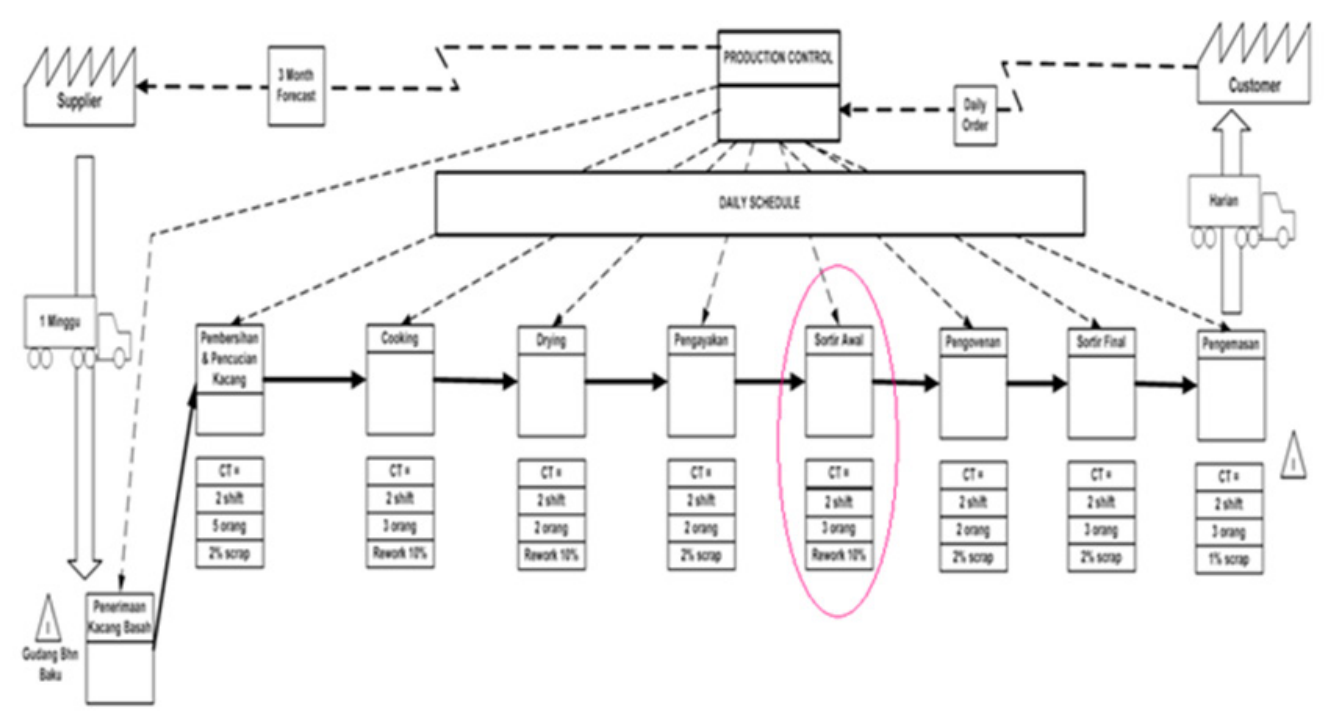

Gambar 2. Big Picture Mapping produk amatan

Berdasarkan keseluruhan aktivitas pada proses produksi kacang teridentifikasi bahwa $62 \%$ merupakan value added activity, $20 \%$ merupakan necessary but non value added activity, dan $18 \%$ merupakan non value added activity. Munculnya non value added activity 
menunjukkan adanya waste dan proses yang tidak efisien. Pemborosan ini bila dibiarkan akan menyebabkan terjadinya pemborosan lain yang tidak pernah diperhitungkan.

Tahap berikutnya adalah identifikasi terhadap non value added activity yang mencirikan adanya waste (pemborosan). Beberapa waste yang muncul misalnya, Defects, yaitu cacat produk akibat kesalahan proses produksi yang mengakibatkan kualitas produk menjadi berkurang/ buruk. Beberapa diantaranya adalah pecah, bolong, burik, bujel, muda/cenos, biji panjang, kulit kotor/busam, kerusakan film, kerusakan dos pengepak. Inappropriate processing, terlihat dari kesalahan dalam penggunaan peralatan, dan adanya proses yang berlebihan. Underutilized People, menunjukkan adanya ketidak mampuan pekerja untuk menyelesaikan pekerjaan. Identifikasi waste dilakukan dengan penyebaran kuisioner dan dapat diperoleh waste paling berpengaruh seperti tabel 1 di bawah ini. Pengisi kuisener adalah kryawan yang terlibat langsung dengan proses produksi yang memahami secara detail problem di proses produksi.

Tabel 1. Ranking Waste Proses produksi

\begin{tabular}{|l|c|c|c|c|c|c|c|c|c|c|}
\hline \multirow{2}{*}{\multicolumn{1}{|c|}{ Jenis Waste }} & \multicolumn{7}{|c|}{ Peringkat } & \multirow{2}{*}{ Bobot } & \multirow{2}{*}{ Ranking } \\
\cline { 2 - 12 } & $\mathbf{1}$ & $\mathbf{2}$ & $\mathbf{3}$ & $\mathbf{4}$ & $\mathbf{5}$ & $\mathbf{6}$ & $\mathbf{7}$ & $\mathbf{8}$ & & \\
\hline $\begin{array}{l}\text { Inappropriate } \\
\text { Processing }\end{array}$ & 9 & 1 & 2 & 1 & 1 & 1 & 0 & 0 & 88 & $\mathbf{1}$ \\
\hline Defect & 1 & 5 & 7 & 0 & 0 & 1 & 1 & 0 & 75 & $\mathbf{2}$ \\
\hline $\begin{array}{l}\text { Underutilized } \\
\text { People }\end{array}$ & 1 & 5 & 3 & 5 & 1 & 0 & 0 & 0 & 75 & $\mathbf{2}$ \\
\hline $\begin{array}{l}\text { Excessive } \\
\text { Transportation }\end{array}$ & 1 & 1 & 3 & 6 & 3 & 0 & 1 & 0 & 62 & 3 \\
\hline Excessive Motion & 1 & 2 & 0 & 2 & 4 & 5 & 0 & 1 & 49 & 4 \\
\hline Waiting & 2 & 1 & 0 & 0 & 2 & 4 & 6 & 0 & 40 & 5 \\
\hline Excessive Motion & 0 & 0 & 0 & 1 & 5 & 0 & 4 & 5 & 23 & 6 \\
\hline Overproduction & 0 & 0 & 0 & 0 & 0 & 3 & 3 & 9 & 9 & 7 \\
\hline \multicolumn{1}{|c|}{ Bobot } & 7 & 6 & 5 & 4 & 3 & 2 & 1 & 0 & & \\
\hline
\end{tabular}

Untuk mengetahui performansi kondisi awal maka dihitung kapabilitas proses produksi berdasarkan produk defect selama 6 pereoda dapat dilihat pada gambar 3 .
Kapabilitas proses produksi yang diakibatkan oleh adanya defect terlihat semakin menurun. Artinya bahwa proses semakin memburuk.

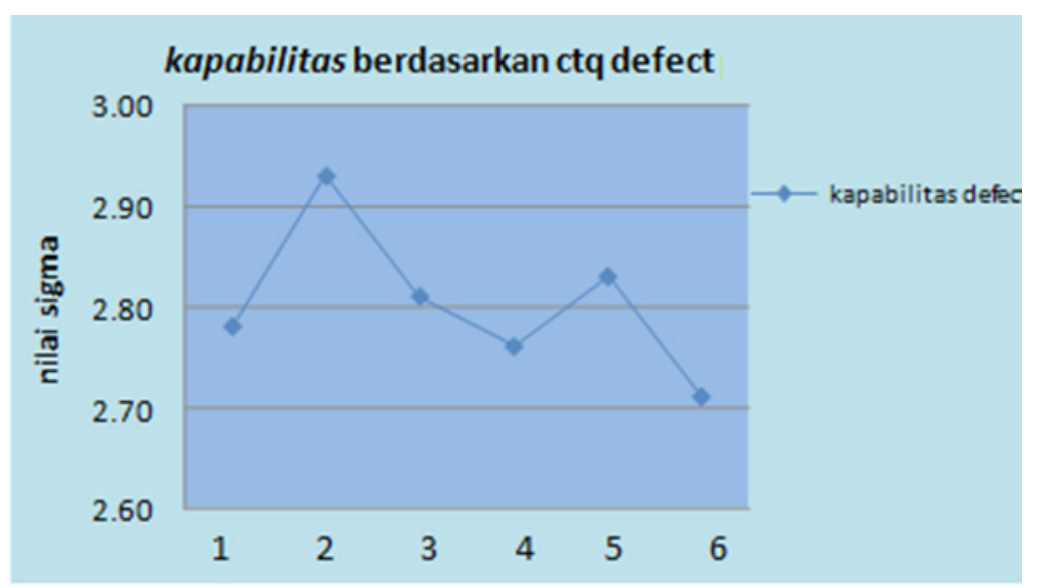

Gambar 3. Kapabilitas proses berdasarkan defect waste 
Berdasarkan perhitungan sigma seperti ditunjukkan di atas diketahui nilai sigma dari defect tersebut adalah berkisar pada angka 2,80 . Selanjutnya untuk mengetahui sebab terjadinya permasalahan kualitas maka dapat dijabarkan dengan pendekatan RCA (Root cause Analysis). Tujuan dari penjabaran dengan RCA adalah untuk mengetahui akar penyebab terjadinya permasalahan defect waste pada proses produksi. Penelusuran akar penyebab masalah sangat penting untuk menunjukkan sebab utama terjadinya problem kualitas. Proses penelusurannya dengan memakai 5 why seperti dijabarkan table 2 di bawah ini.

Tabel 2. Tabel RCA (Root Cause Analysis) dari Defect waste

\begin{tabular}{|c|c|c|c|c|c|}
\hline Waste & $\begin{array}{c}\text { sub } \\
\text { waste }\end{array}$ & why 1 & why 2 & why 3 & Why 4 \\
\hline \multirow{10}{*}{ Defect } & Afal film & $\begin{array}{l}\text { Kesalahan proses } \\
\text { packing }\end{array}$ & $\begin{array}{l}\text { kerusakan film dari } \\
\text { supplier } \\
\text { kesalahan pemasangan } \\
\text { dan pengoperasian } \\
\text { film }\end{array}$ & $\begin{array}{l}\text { petugas pemesan } \\
\text { tidak teliti } \\
\text { operator kurang } \\
\text { hati hati }\end{array}$ & $\begin{array}{l}\text { operator tidak hati- } \\
\text { hati }\end{array}$ \\
\hline & & $\begin{array}{l}\text { kesalahan } \\
\text { penerimaan bahan } \\
\text { baku }\end{array}$ & $\begin{array}{l}\text { kacang berjenis kulit } \\
\text { tipis dan rapuh }\end{array}$ & $\begin{array}{l}\text { terlalu lama } \\
\text { disimpan dalam } \\
\text { sekbin/selo }\end{array}$ & $\begin{array}{l}\text { permintaan yang } \\
\text { tidak stabil }\end{array}$ \\
\hline & pecah & $\begin{array}{l}\text { tidak hati-hati } \\
\text { dalam proses } \\
\text { material handling }\end{array}$ & $\begin{array}{l}\text { benturan material } \\
\text { antara mesin (drying } \\
\text { dan oven) dan belt } \\
\text { conveyor }\end{array}$ & $\begin{array}{l}\text { benturan kacang } \\
\text { dari mesin gravity } \\
\text { saat sortir oleh } \\
\text { fork lift }\end{array}$ & $\begin{array}{l}\text { tidak ada alat dari } \\
\text { proses gravity ke } \\
\text { sortir }\end{array}$ \\
\hline & & $\begin{array}{l}\text { Kesalahan pada } \\
\text { proses penyortiran }\end{array}$ & Skill operator kurang & $\begin{array}{l}\text { Operator tidak } \\
\text { teliti }\end{array}$ & $\begin{array}{l}\text { Operator kurang } \\
\text { hati - hati dalam } \\
\text { penyortiran }\end{array}$ \\
\hline & \multirow{4}{*}{ Burik } & $\begin{array}{l}\text { kesalahan dalam } \\
\text { proses pengayakan }\end{array}$ & $\begin{array}{l}\text { pemisahan kurang } \\
\text { bagus di mesin gravity }\end{array}$ & $\begin{array}{l}\text { set up mesin } \\
\text { gravity yang } \\
\text { kurang }\end{array}$ & operator lalai \\
\hline & & $\begin{array}{l}\text { kesalahan } \\
\text { penerimaan bahan } \\
\text { baku kacang }\end{array}$ & $\begin{array}{l}\text { Bahan kacang tidak } \\
\text { sesuai }\end{array}$ & $\begin{array}{l}\text { Operator tidak } \\
\text { teliti } \\
\text { pengambilan } \\
\text { sampel }\end{array}$ & \\
\hline & & $\begin{array}{l}\text { kesalahan proses } \\
\text { sortir }\end{array}$ & Skill operator kurang & $\begin{array}{l}\text { Operator tidak } \\
\text { teliti }\end{array}$ & Operator lalai \\
\hline & & $\begin{array}{l}\text { kesalahan pada } \\
\text { proses penyortiran }\end{array}$ & Skill operator kurang & $\begin{array}{l}\text { operator tidak } \\
\text { teliti }\end{array}$ & $\begin{array}{l}\text { Operator kurang } \\
\text { hati - hati dalam } \\
\text { penyortiran }\end{array}$ \\
\hline & \multirow[t]{2}{*}{ Muda/cenos } & $\begin{array}{l}\text { kesalahan dalam } \\
\text { proses pengayakan } \\
\text { dan pemisahan } \\
\text { kacang }\end{array}$ & $\begin{array}{l}\text { proses pemisahan dan } \\
\text { kontrolan yang kurang } \\
\text { bagus di mesin } \\
\text { gravity }\end{array}$ & $\begin{array}{l}\text { set up mesin } \\
\text { gravity yang } \\
\text { kurang }\end{array}$ & $\begin{array}{l}\text { operator kurang } \\
\text { teliti }\end{array}$ \\
\hline & & $\begin{array}{l}\text { kesalahan pada } \\
\text { proses penyortiran }\end{array}$ & Skill operator kurang & $\begin{array}{l}\text { operator tidak } \\
\text { teliti }\end{array}$ & $\begin{array}{l}\text { Operator kurang } \\
\text { hati - hati dalam } \\
\text { penyortiran }\end{array}$ \\
\hline
\end{tabular}

Dengan telah ditemukannya akar penyebab timbulnya waste maka analisa dilanjutkan pada pencarian prioritas untuk quality improvement. Tools yang dipakai adalah FMEA (failure mode and effects analysis). Hasil akhir dari identifikasi FMEA adalah nilai RPN. Nilai RPN (risk priority number) adalah nilai yang dihasilkan dari perkalian nilai severity (sev.), occurrence (occ.) dan Detection. Nilai ini dipakai sebagai 
acuan untuk memilih prioritas perbaikan untuk menaikkan kualitas. Nilai RPN untuk defect waste dapat dilihat pada tabel 3 di bawah ini.
Berdasarkan pada nilai RPN maka dipilih RPN tertinggi untuk generate alternative solusi.

Tabel 3. Nilai RPN untuk Defect Waste

\begin{tabular}{|c|c|c|c|c|c|c|c|c|}
\hline Waste & Sub Waste & Effect & $\mathrm{Sev}$ & Cause & $O c c$ & Control & Det & $R P N$ \\
\hline \multirow{11}{*}{ Defect } & \multirow{2}{*}{ Afal film } & \multirow{9}{*}{$\begin{array}{l}\text { Tidak dapat } \\
\text { memenuhi } \\
\text { kepuasaan } \\
\text { pelanggan }\end{array}$} & \multirow{2}{*}{4} & $\begin{array}{l}\text { Petugas pemesan kurang hati } \\
\text {-hati }\end{array}$ & 6 & visual & 4 & 96 \\
\hline & & & & $\begin{array}{l}\text { operator kurang hati-hati } \\
\text { dalam pengoperasian mesin }\end{array}$ & 7 & $\begin{array}{l}\text { standar } \\
\text { mesin }\end{array}$ & 5 & 140 \\
\hline & \multirow{3}{*}{ Pecah } & & \multirow{3}{*}{4} & $\begin{array}{l}\text { Jumlah permintaan yang } \\
\text { kurang dan tidak stabil }\end{array}$ & 7 & checklist & 4 & 112 \\
\hline & & & & $\begin{array}{l}\text { tidak adanya belt conveyor } \\
\text { dari gravity ke tempat } \\
\text { penyortiran }\end{array}$ & 7 & visual & 4 & 112 \\
\hline & & & & $\begin{array}{l}\text { Operator kurang hati - hati } \\
\text { (teliti) dalam penyortiran }\end{array}$ & 8 & Visual & 4 & 128 \\
\hline & \multirow{4}{*}{ Burik } & & \multirow{4}{*}{4} & $\begin{array}{l}\text { set up mesin gravity yang } \\
\text { kurang tepat }\end{array}$ & 6 & $\begin{array}{l}\text { standar } \\
\text { mesin }\end{array}$ & 5 & 120 \\
\hline & & & & $\begin{array}{l}\text { operator kurang teliti untuk } \\
\text { sampel bahan baku kacang }\end{array}$ & 6 & visual & 4 & 96 \\
\hline & & & & $\begin{array}{l}\text { operator kurang hati- } \\
\text { hati(teliti) dalam penyortiran }\end{array}$ & 7 & visual & 4 & 112 \\
\hline & & & & $\begin{array}{l}\text { operator kurang hati-hati } \\
\text { (teliti) dalam penyortiran }\end{array}$ & 7 & visual & 4 & 72 \\
\hline & \multirow{2}{*}{ Muda/cenos } & & \multirow{2}{*}{4} & $\begin{array}{l}\text { set up mesin gravity yang } \\
\text { kurang tepat }\end{array}$ & 7 & $\begin{array}{l}\text { standar } \\
\text { mesin }\end{array}$ & 5 & 140 \\
\hline & & & & $\begin{array}{l}\text { operator kurang hati-hati } \\
\text { (teliti) dalam penyortiran }\end{array}$ & 8 & visual & 4 & 128 \\
\hline
\end{tabular}

Dari tabel 3 tentang nilai RPN di atas dapat ditentukan alternatif solusi perbaikan yang dipilih menaikkan kualitas produk kacang. Tiga alternatif yang mungkin dapat dikerjakan adalah 1, pelatihan operator, 2, pembuatan SOP (system operating procedure) proses produksi, dan 3, pelatihan untuk pekerja quality control.

Tahap terakhir adalah analisa biaya memakai pendekatan metode profitability analysis dengan perhitungan NPV (Net Present Value). Analisis ini didahului dengan memilah aktifitas yang termasuk dalam kategori non added value dan mengeluarkan biaya. Apabila solusi alternatif dijalankan maka terjadi pengurangan lead time, dan selanjutnya akan diperoleh benefit karena berkurangnya waiting waste dan bertambahnya kesempatan untuk menghasilkan produksi.
Bila alternatif terpilih dijalankan maka benefit yang diperoleh dari pengurangan inappropriate processing waste, adalah berkisar $\approx 530$ produk, asumsi bahwa harga per bungkus adalah $\mathrm{Rp} 9.000,-$, maka benefit yang diperoleh $=530 \times \mathrm{Rp} 9.000,-=\mathrm{Rp}$. 4.770.000,-

Dipandang dari kesempatan utuk berproduksi, karena munculnya produk cacat, maka bila alternatif solusi dijalankan, benefit yang diperoleh adalah berkisar $\approx 260$ produk, atau 260 x Rp. 9.000,- = Rp. 2.340.000,-

Untuk pengurangan underutilized people yang menyebabkan inappropriate processing dan defect waste memerlukan biaya investasi sebesar Rp. 26.800.000,- Biaya tersebut diantaranya dipakai untuk investasi berupa pelatihan operator, pembuatan system operating procedure serta fasilitas pendukungnya, dengan umur investasi adalah 5 tahun, maka, 
$\mathrm{NPV}=\{-\mathrm{Rp} .26 .800 .000,-+$ Rp. $(4.770 .000$ $+2.340 .000)(\mathrm{P} / \mathrm{A}, 5 \%, 5)\}=$ Rp. 5.648.618,(positif)

Net present value (NPV) adalah positif, nilai ini memberi indikator bahwa solusi alternatif adalah layak untuk dijalankan.

Dengan adanya pemikiran kreatif untuk membangun keunggulan kompetitif, maka solusi alternatif yang layak untuk dijalankan tersebut adalah merupakan pola memaksimalkan seluruh pemakaian sumber daya perusahaan yang bersifat continuous process improvement (CPI) untuk dapat menghasilkan produk yang semakin berkualitas. Konsep CPI ini adalah yang menjadi dasar bagi peningkatan daya saing perusahaan. Faktor daya saing menjadi penting dan semakin berkembang seiring dengan semakin berkembangnya produk yang dapat memasuki pasar global. Kemampuan untuk menurunkan tingkat defect waste yang disebabkan oleh inappropriate processing, defect dan underutilized people waste adalah faktor yang penting untuk membangun pemberdayaan (empowerment) dan daya saing produk. Artinya bahwa kepuasan konsumen adalah merupakan inti di dalam membangun, memberdayakan dan menaikkan daya saing produk. Selanjutnya konsep di atas dapat digambarkan dalam bentuk gambar 4 seperti di bawah ini,

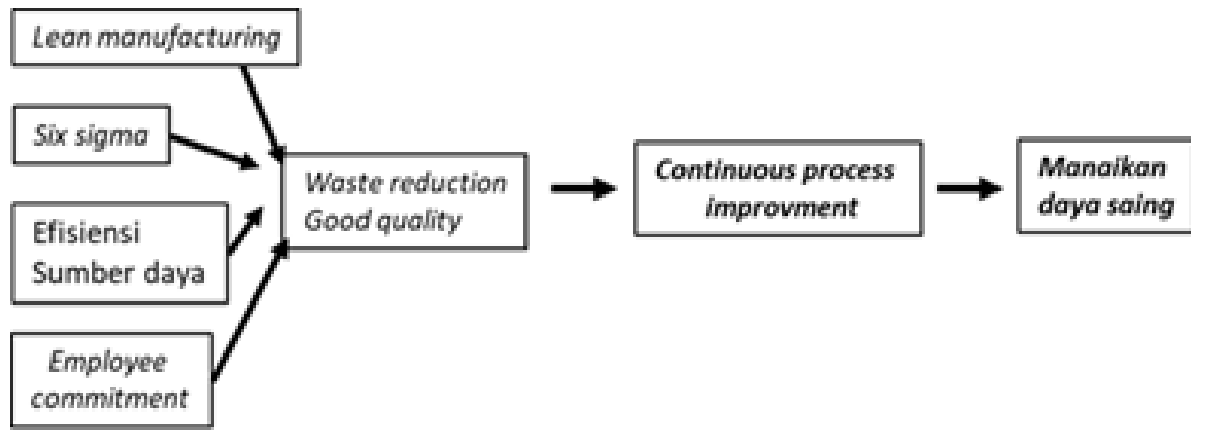

Gambar 4. Cara menaikkan daya saing industri

Penerapan solusi alternatif dengan analisa yang disebutkan di atas dapat menurunkan defect per million opportunity (DPMO), dan menaikkan nilai sigma dari kisaran 2,8 menjadi 3,3. Nilai sigma ini menunjukkan bahwa kualitas produk yang baik akan semakin tinggi, artinya bahwa konsumen akan mendapatkan produk yang semakin baik. Keberhasilan menurunkan waste ini harus dilanjutkan untuk pereoda berikutnya, dengan tujuan untuk menaikkan nilai sigma. Dengan adanya penurunan DPMO dan kenaikan sigma tersebut dapat dilihat bahwa di satu sisi terdapat keuntungan yang diperoleh dari semakin banyaknya produk yang baik dan di sisi yang lain terjadi reduction cost sampai $20 \%$.

\section{KESIMPULAN DAN SARAN.}

Beberapa kesimpulan yang dapat diambil adalah:
1. Identifikasi terhadap 8 waste dapat ditemukan bahwa waste yang paling sering terjadi adalah inappropriate processing, defect, dan underutilized people waste.

2. Alternatif perbaikan berupa pembuatan SOP, pelatihan para operator dan pelatihan karyawan quality control merupakan rekomendasi terbaik untuk mereduksi waste.

3. Nilai sigma untuk defect waste kondisi awal adalah 2,80 dan setelah dilakukan improvement ternyata mampu menaikkan nilai sigma menjadi 3.30. dan terjadi reduksi biaya sampai $20 \%$.

\section{SARAN.}

Identifikasi waste (pemborosan) di sepanjang aliran proses produksi akan menjadi 
lain ketika riset dilakukan pada bidang produksi atau jasa dengan jenis produk dan jasa yang berbeda, apalagi dengan penggunaan teknologi proses yang berbeda. Perubahan data yang muncul akan menunjukkan apakah terjadi pergeseran waste yang kritis. Untuk itu riset ini akan menjadi lebih berwarna ketika ditunjang dengan data-data yang lebih akurat.

\section{DAFTAR PUSTAKA}

Dora, M., Van Goubergen, D., Kumar, M., Molnar, A. and Gellynck, X. 2014. Application of lean practices in SME food enterprises. British Food Journal, 116, 1 pp. 125-141

Ga, M., Yang, M., Hong, P. and Modi, S. B. 2011. Impact of Lean Manufacturing and Environmental Management on Business Performance: An Empirical Study of Manufacturing Firm. Journal of Production Economic, 129 (2) pp. 251-261

Gaspersz, V. 2007. Lean Six Sigma for Manufacturing and Service Industries. PT Gramedia Pustaka Utama, Jakarta

Gibbons, P.M. and Burgers, S.C. 2010. Improving OEE as a measure of lean six sigma capability, International Journal of Lean Six Sigma, Vol.10 No. 2 pp. 134-156. (14)

Harisupriyanto, 2013. Seminar on Aplication and research in industrial technology (SMART);' Generate alternatif solusi berdasarkan reduksi waste dan RCA', ISBN: 978-60214272-0-0 hal. D-25, UGM, Yogyakarta

Harisupriyanto and Diesta I. M. 2017. A Lean six-sigma manufacturing process case study, International Journal of Mechanical Engineering and Technology (IJMET), Vol. 8, Iss. 7, pp. 01-11,

Hines, Peter, and Taylor, D. 2000. "Going Lean". Proceeding of Lean Enterprise Research Centre Cardiff Business School, UK

Pande, P.S, Neuman, R. P, and Roland R. Cavanagh. 2002. The Six Sigma Way: Team Fieldbook, an Implementation Guide for Process Improvement. McGraw-Hill

Pyzdek, T. and Keller, P. 2010. The six sigma handbook: a complete guide for green belts, black belts, and managers at all levels. USA: McGraw-Hill

Taylor, D. and Brunt, D. 2001. Manufacturing Operations and Supply Chain Management : The Lean Approach. High Holborn, London: Thomson Learning. 